\title{
STRATEGI PENGOLAHAN LIMBAH CAIR PABRIK KELAPA SAWIT DI PT. AMP PLANTATION JORONG TAPIAN KANDIH NAGARI SALAREH AIA KECAMATAN PALEMBAYAN KABUPATEN AGAM
}

\author{
Mulza Rois, Haviza Fresillia \\ Jurusan Pendidikan Geografi, Sekolah Tinggi Keguruan dan Ilmu Pendidikan \\ (STKIP) Ahlussunnah Bukittinggi \\ Email:rois.mulza@gmail.com
}

\begin{abstract}
Abstrak
Penelitian ini bertujuan untuk mendeskripsikan strategi pengolahan limbah cair pabrik kelapa sawit di PT AMP Plantation di Jorong Tapian Kandih Nagari Salareh Aia Kecamatan Palembayan Kabupaten Agam. Jenis penelitian ini adalah penelitian kualitatif dengan metode deskriptif. Informan dalam penelitian ini adalah karyawan perusahaan dan masyarakat yang tinggal disekitar tempat pembuangan limbah cair tersebut. Teknik pengambilan informan dari penelitian ini diambil secara purposive sampling. Teknik pengumpulan data yang digunakan dalam penelitian ini adalah observasi, wawancara dan dokumentasi. Sedangkan teknik analisa data yang digunakan adalah reduksi data, display data, dan penarikan kesimpulan. Hasil dari penelitian ini menunjukkan bahwa strategi pengolahan limbah cair kelapa sawit di PT AMP Plantation ini belum memenuhi standar Peraturan Menteri Perindustrian RI No 111/MIND/PER/10/2009. Karena hanya memiliki empat jenis kolam penyaringan saja sedangkan menurut standarnya sebuah perusahaan harus memiliki lima jenis kolam penyaringan dengan cabangnya masing-masing. Kolam penyaringan yang dimiliki oleh PT AMP Plantation yang pertama adalah: 1. Fat Pit Pada fat pit ini terjadi pemanasan dengan menggunakan steam dari $B P V$. Limbah dari fat pit ini kemudian dialirkan ke kolam cooling pond yang berguna untuk mendinginkan limbah yang telah dipanaskan. 2. Cooling Pond yaitu selain untuk mendinginkan limbah, cooling pond juga berfungsi untuk mengendapkan sludge. Setelah dari cooling pond I limbah kemudian masuk ke cooling pond II untuk dilakukan proses pendinginan yang sama dengan cooling pond I. 3. Kolam Anaerobic dalam kolam ini terjadi perlakuan biologis terhadap limbah dengan menggunakan bakteri metagonik yang telah ada di kolam. 4. Kolam Aplikasi setelah disaring dari kolam anaerobik limbah kemudian masuk ke kolam aplikasi yang merupakan tempat pembuangan akhir limbah.
\end{abstract}

Kata Kunci:Strategi pengelohan,Limbah Cair,PT.Amp.Plantation

\section{PENDAHULUAN}

Berdasarkan Peraturan Pemerintah Republik Indonesia No. 104 tahun 2014 tentang Pengelolaan Limbah Bahan Berbahaya dan Beracun bahwa Bahan Berbahaya dan Beracun yang selanjutnya disingkat B3 adalah zat, energi, atau komponen lain yang karena sifat, konsentrasi, dan jumlahnya baik secara langsung maupun tidak langsung dapat mencemarkan atau merusak lingkungan hidup, dan membahayakan lingkungan hidup, kesehatan, serta kelangsungan hidup manusia dan makhluk hidup lain.

\section{Menurut Kristanto (2016:232)} limbah cair yaitu buangan air yang digunakan untuk mendinginkan mesin suatu pabrik. Misalnya suatu pabrik membutuhkan air untuk mendinginkan mesin maka pabrik tersebut memanfaatkan air yang sudah tercemar akibat aktivitas pabrik lain. Selanjutnya dalam jurnal ilmiah Fatimah (2017:2) bahwa limbah cair adalah salah satu produk samping dari pabrik minyak kelapa sawit yang berasal dari kondensat dari proses sterilisasi, air dari proses klarifikasi, air hydrocyclone (claybath), dan air pencucian pabrik. Limbah cair pabrik kelapa sawit 
mengandung berbagai senyawa terlarut termasuk, serat-serat pendek, hemiselulosa dan turunannya, protein, asam organik bebas dan campuran mineral-mineral.

Salah satu limbah yang termasuk ke dalam kategori limbah Bahan Berbahaya dan Beracun (B3) adalah limbah cair yang dihasilkan oleh pabrik kelapa sawit yang menghasilkan minyak goreng. Limbah cair pabrik kelapa sawit merupakan salah satu produk samping berupa buangan dari pabrik pengolahan kelapa sawit. Limbah cair ini tidak dapat langsung dibuang ke perairan atau daratan karena memiliki kadar bahan organik yang tinggi.

Limbah cair pabrik kelapa sawit terbagi atas dua yaitu lumpur primer yang dihasilkan dalam proses pengolahan kelapa sawit, sedangkan lumpur sekunder adalah lumpur yang telah mengalami proses sedimentasi (Fauzi dkk,2003:144). Karena air buangan dari suatu pabrik membawa sejumlah padatan dan partikel, baik yang larut maupun mengendap dan kerap kali air buangan pabrik berwarna keruh dan bersuhu tinggi sehingga berbahaya bagi lingkungan (Kristanto,2013:233). Kelapa sawit telah menjadi primadona dalam komoditi eksport negara Indonesia. Namun dibalik kesuksesan tersebut, suatu konsekuensi lain adalah timbulnya permasalahan limbah. Hampir semua pabrik kelapa sawit, bahkan yang sudah mengeksport minyak mentah kelapa sawit mempunyai kelemahan dalam hal penanganan limbahnya terutama limbah cairnya. Limbah cair yang dihasilkan oleh perusahaan minyak kelapa sawit harus diolah agar tidak memberikan dampak negatif bagi manusia ataupun lingkungannya.

Permasalahan ini juga dialami oleh salah satu pabrik pengolahan minyak kelapa sawit yang terdapat di Kabupaten Agam yaitu PT AMP Plantation. PT AMP Plantation merupakan pabrik besar sebagai produsen minyak goreng di Sumatra Barat. PT AMP Plantation ini merupakan sebuah perusahaan yang memiliki asset kebun sawit yang terbesar di Sumatra Barat. Sehingga hasil produksi minyak goreng dari perusahaan ini sangat besar karena didukung oleh persediaan bahan baku kelapa sawitnya yang tinggi.

Hasil produksi PT AMP Plantation yang tinggi maka limbah cair yang dihasilkan oleh pabrik ini juga tinggi sehingga menjadi permasalahan bagi lingkungan sekitar. Tempat pembuangan limbah cair pabrik kelapa sawit di PT AMP Plantation yang terletak di Jorong Tapian Kandih Nagari Salareh Aia terletak sekitar 2 $\mathrm{km}$ dari lingkungan pabrik dan berada dekat dengan tempat pemukiman penduduk yang bekerja di PT ini. Setelah dilakukan Pemantauan di PT AMP Plantation ternyata strategi pengolahan limbah cair pabrik kelapa sawit di perusahaan ini tidak memiliki kolam penyaringan yang lengkap karena hanya memiliki empat buah kolam penyaringan saja. Sehingga memberikan permasalahan bagi penduduk yang bermukim disana karena bau limbah cair yang menyengat, banyaknya jentik-jentik nyamuk yang berkembang karena genangan air limbah, serta merusak pandangan mata kita karena warna limbahnya yang hitam dan keruh. Selain itu, limbah cair ini juga menyebabkan berkurangnya kualitas tanah yang berada disekitar tempat pembuangan limbah cair. Kalau kualitas tanah sudah berkurang maka kualitas air tanah yang dihasilkan juga akan berkurang sehingga apabila kita konsumsi dan gunakan bisa membahayakan kesehatan tubuh manusia.

Limbah cair yang dihasilkan oleh pengolahan kelapa sawit berasal dari kondesat, stasiun klarifikasi dan dari hidrosilikon. Limbah cair ini memiliki kadar bahan organik yang tinggi Limbah cair kelapa sawit menghasilkan lumpur primer dan lumpur sekunder. Lumpur primer berasal dari proses klarifikasi limbah cair yang dihasilkan dalam proses pengolahan kelapa sawit, sedangkan lumpur yang telah mengalami proses sedimentasi disebut lumpur sekunder (Fauzi dkk,2003:144). Selanjutnya menurut Siregar (2005:21) karakter fisika limbah cair meliputi temperatur, bau, warna, dan padatan sedangkan karakter kimianya adalah 
meliputi senyawa organik dan senyawa anorganik dan karakter biologi limbah cair adalah mikroorganismenya. Karakteristik limbah cair pabrik kelapa sawit dapat dilihat melalui tabel sebagai berikut:

Tabel 1. Karakteristik limbah cair kelapa sawit

\begin{tabular}{|l|c|c|}
\hline \multicolumn{1}{|c|}{ Parameter } & $\begin{array}{c}\text { Lumpur } \\
\text { Primer }\end{array}$ & $\begin{array}{c}\text { Lumpur } \\
\text { Sekunder }\end{array}$ \\
\hline $\mathrm{pH}$ & 3,75 & 4,54 \\
\hline Padatan Tersuspensi (ppm) & 80,720 & 243.670 \\
\hline Padatan Volatil (ppm) & 64,760 & 233.730 \\
\hline COD (ppm) & 28,220 & 16.320 \\
\hline Nitrat (ppm) & 31 & 3 \\
\hline Fosfat (ppm) & 106 & 3 \\
\hline
\end{tabular}

Sumber : Menurut Nurcahyo dalam Fauzi dkk (2003:144)

Golongan parameter yang dapat digunakan sebagai tolak ukur penilaian karakteristik limbah cair adalah sebagai berikut:

1. COD (Chemical Oxygen Demand) yang merupakan ukuran untuk senyawa organik yang dapat dibiodegradasi atau tidak

2. BOD (Biochemical Oxygen Demand) yang merupakan senyawa kadar organik yang dapat dibiodegradasi dalam limbah cair.

3. TOC (Total Organic Carbon) dan TOD (Total Oxygen Demand) yang merupakan ukuran untuk kandungan senyawa organik keseluruhan.

4. Padatan tersuspensi dan teruapkan (suspended and volatile solids)

5. Kandungan padatan keseluruhan.

6. $\mathrm{pH}$ alkalinitas dan keasaman.

7. Kandungan nitrogen dan posfor.

8. Kandungan logam berat.

Komposisi limbah cair meliputi $76 \%$ BOD yang berasal dari padatan tersuspensi dan hanya $224 \%$ dari padatan terlarut. Maka banyak tidaknya padatan yang terdapat terdapat dalam limbah terutama padatan tersuspensi mempengaruhi tinggi rendahnya $\mathrm{BOD}$ limbah cair pabrik kelapa sawit memiliki potensi sebagai pencemar lingkungan karena berbau, mengandung nilai COD dan BOD serta padatan tersuspensi yang tinggi.
Apabila limbah tersebut langsung dibuang sembarangan maka sebagian akan mengendap, terurai secara perlahan, mengonsumsi oksigen terlarut, menimbulkan kekeruhan, mengeluarkan bau yang sangat tajam. Limbah cair pabrik kelapa sawit mengandung senyawa anorganik dan organik yang dapat dan tidak dapat dirombak oleh mikroorganisme. Limbah yang mengandung senyawa organik umumnya dapat dirombak oleh bakteri dan dapat dikendalikan secara biologis. Pengolahan limbah cair secara biologis dapat dilakukan dengan proses aerobik dan anaerobik

\section{METODE PENELITIAN}

Jenis penelitian ini adalah penelitian kualitatif dengan metode deskriptif yaitu sebuah penelitian yang berusaha memberikan gambaran mengenai objek yang diamati atau diteliti, sesuai dengan kenyataan di lapangan. Menurut Arikunto (2006:12) mengemukakan bahwa penelitian kualitatif menunjukkan bahwa pelaksanaan penelitian ini terjadi secara alami, apa adanya dalam situasi normal yang tidak dimanipulasi keadaan dan kondisinya dan dituntut keterlibatan penelitian secara langsung di lapangan.

Penelitian ini dilaksanakan pada bulan Juli-Agustus 2015. Penelitian dilaksanakan di PT AMP Plantation Jorong Tapian Kandih Nagari Salareh Aia Kecamatan Palembayan Kabupaten Agam.Informan penelitianadalah orang 
yang dimanfaatkan memberikan informasi tentang situasi dan kondisi latar penelitian dalam rangka memperoleh data informasi yang relevan dengan permasalahan penelitian ini maka mengumpulkan data dilakukan pembentukan informan penelitian. Informan penelitian kualitatif bukan dinamakan responden, tetapi sebagai narasumber atau informan. Dalam penelitian ini teknik pengambilan informan adalah purposive sampling.

$$
\text { Menurut Sugiono (2008:28) }
$$

purposive sampling adalah penelitian informan berdasarkan karakteristik tertentu yang dianggap mempunyai sangkut paut dengan karakteristiknya. Dalam penelitian ini yang di jadikan sebagai informan penelitian adalah pihak perusahaan PT AMP Plantations dan masyarakat yang tinggal di sekitar pembuangan limbah cair tersebut.

Dalam penelitian ini ada 2 jenis data yang dikumpulkan yaitu data primer dan data sekunder. Teknik Pengumpulan Data dalam penelitian ini adalah observasi, wawancara dan dokumentasi. Data yang telah dikumpulkan dianalisis dengan pendekatan kualitatif model interaktif, yaitu terdiri dari tiga hal utama yaitu reduksi data, penyajian data dan penarikan kesimpulan/verifikasi. Adapun teknik menguji keabsahan data yang digunakan adalah Perpanjangan keikutsertaan, Ketekunan Pengamatan dan Triangulasi.

\section{HASIL DAN PEMBAHASAN}

Berdasarkan hasil penelitian didapatkan gambaran bahwa strategi pengolahan limbah cair di PT AMP Plantation terdiri dari:

\section{Fat Pit}

Limbah dialirkan masuk kedalam fat pit. Pada fat pit ini terjadi pemanasan dengan menggunakan steam dari BPV. Pemanasan ini diperlukan untuk memudahkan pemisahan minyak dengan sludge sebab pada fat pit ini masih dimungkinkan untuk melakukan pengutipan minyak dengan menggunakamn skimmer. Limbah dari fat pit ini kemudian dialirkan ke kolam cooling pond yang berguna untuk mendinginkan limbah yang telah dipanaskan.

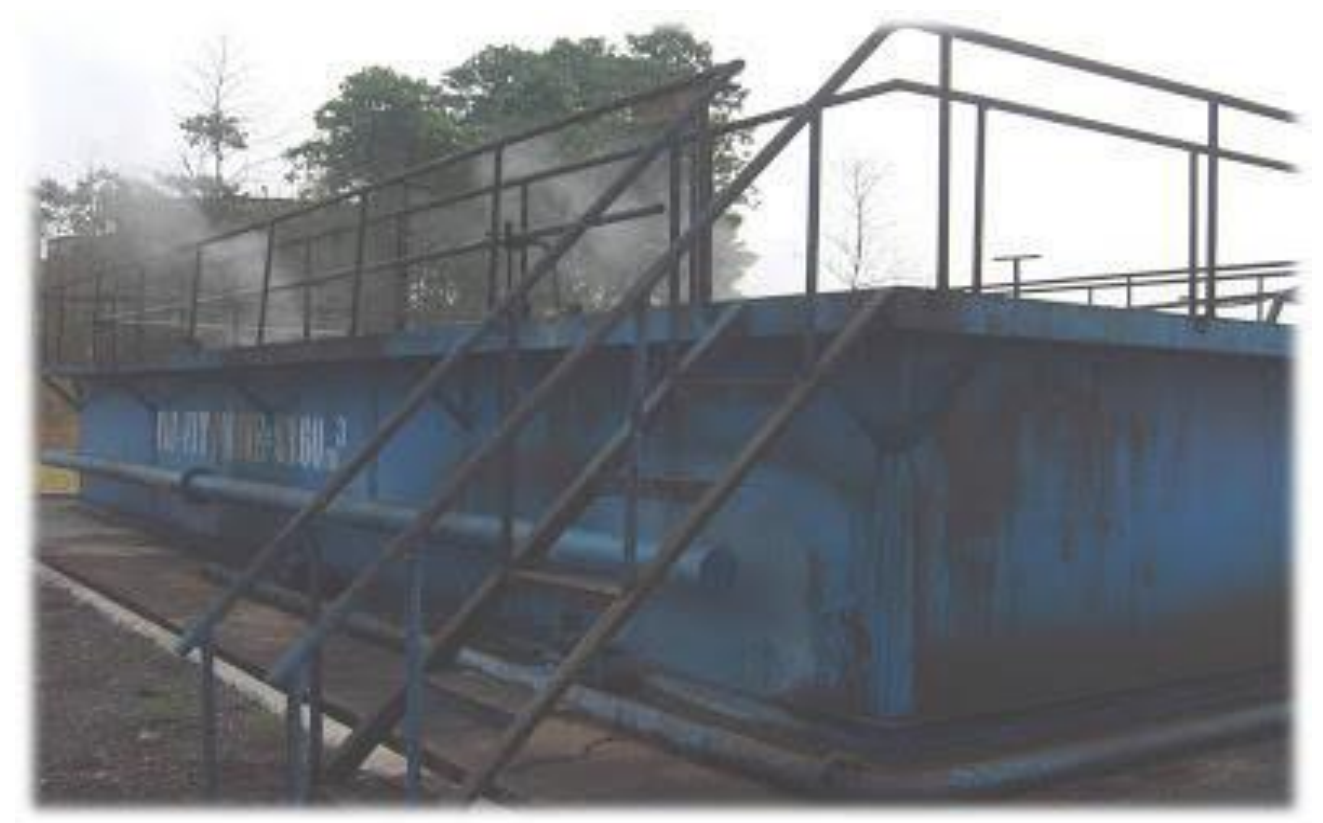

Gambar 1. Kolam fat pit

\section{Cooling Pond}

Selain untuk mendinginkan limbah, cooling pond juga berfungsi untuk mengendapkan sludge. Setelah dari cooling pond I limbah kemudian masuk ke cooling pond II untuk dilakukan proses 
pendinginan yang sama dengan cooling pond I. Limbah dari cooling pond II

kemudian dialirkan ke kolam anaerobic.

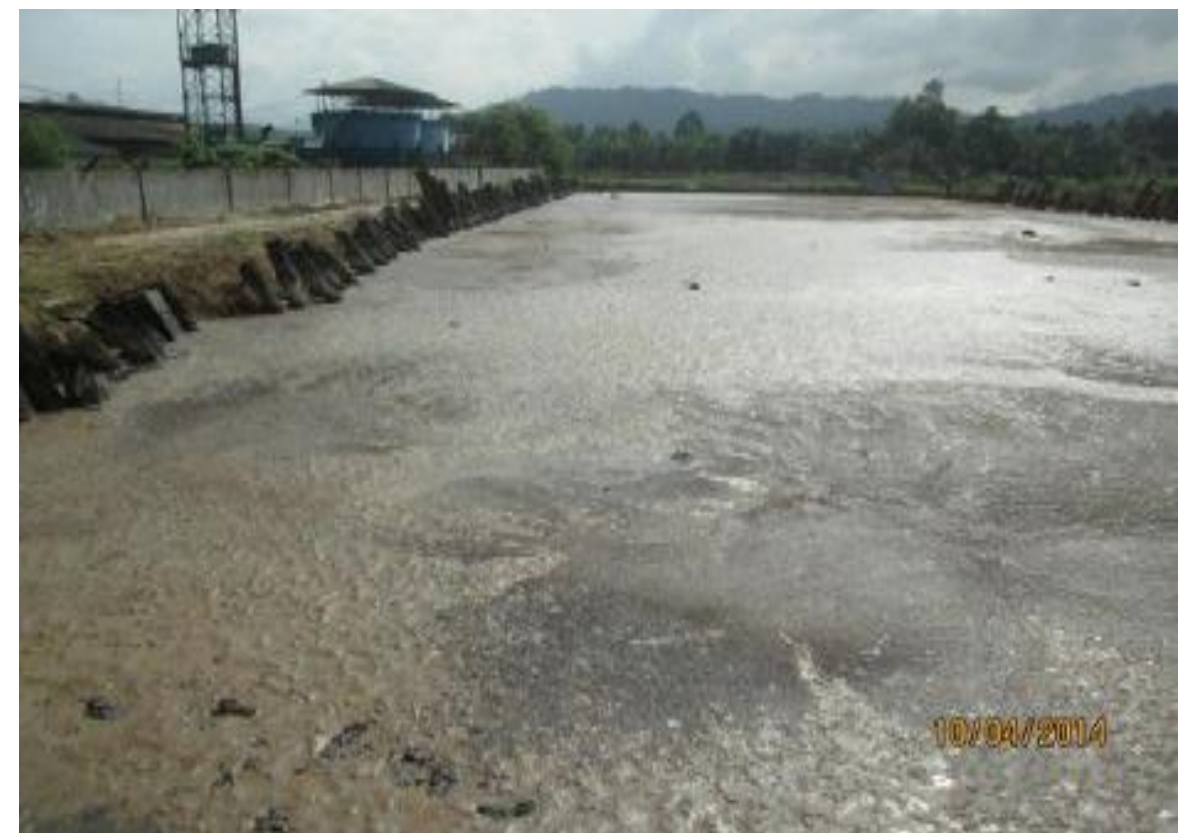

Gambar 2. Kolam cooling pond 1

\section{Kolam Anaerobic}

Pada kolam anaerobic ini terjadi perlakuan biologis terhadap limbah dengan menggunakan bakteri metagonik yang telah ada di kolam. Unsur organik yang terdapat dalam limbah cair digunakan bakteri sebagai makanan dalam proses mengubahnya menjadi bahan yang tidak berbahaya bagi lingkungan. Pada kolam anaerobic terjadi penurunan BOD dan kenaikan $\mathrm{pH}$ minimal 6. Ketebalan scum pada kolam anaerobic tidak boleh $>25$ $\mathrm{cm}$, jika ketebalannya telah melebihi $25 \mathrm{~cm}$ maka itu merupakan tanda bahwa bakteri sudah kurang berfungsi.

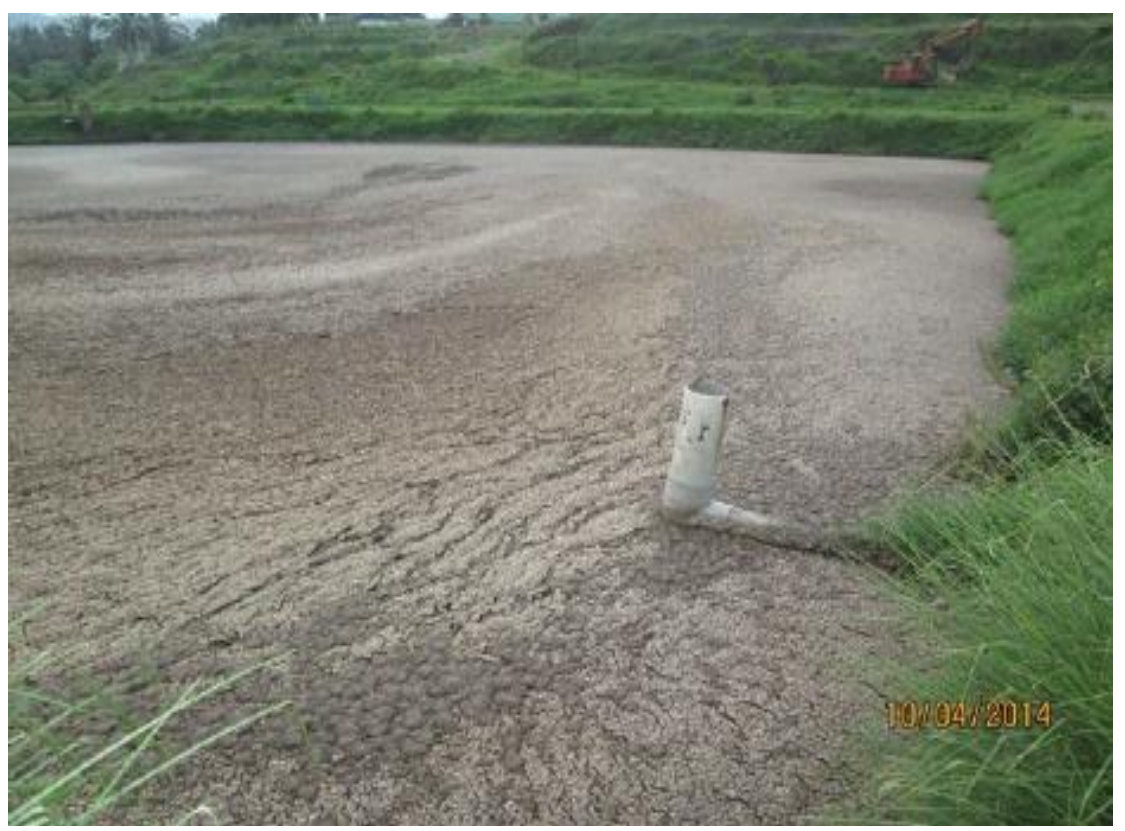

Gambar 3. Kolam anaerobic 
4. Kolam Aplikasi

Setelah disaring dari kolam anaerobik 1 limbah kemudian masuk ke kolam aplikasi yang merupakan tempat pembuangan akhir limbah karena pada kolam sebelumnya limbah cair ini sudah diolah menjadi limbah cair yag tidak berbahaya bagi lingkungan. Secara umum strategi pengolahan limbah cair pabrik kelapa sawit di PT AMP Plantation belum sesuai dengan Peraturan Menteri Perindustrian RI No 111/MIND/PER/10/2009 tentang peta panduan (ROAD MAP) Pengembangan Klaster Industri Pengolahan Kelapa Sawit yang memiliki kolam penyaringan seperti gambar dibawah ini:
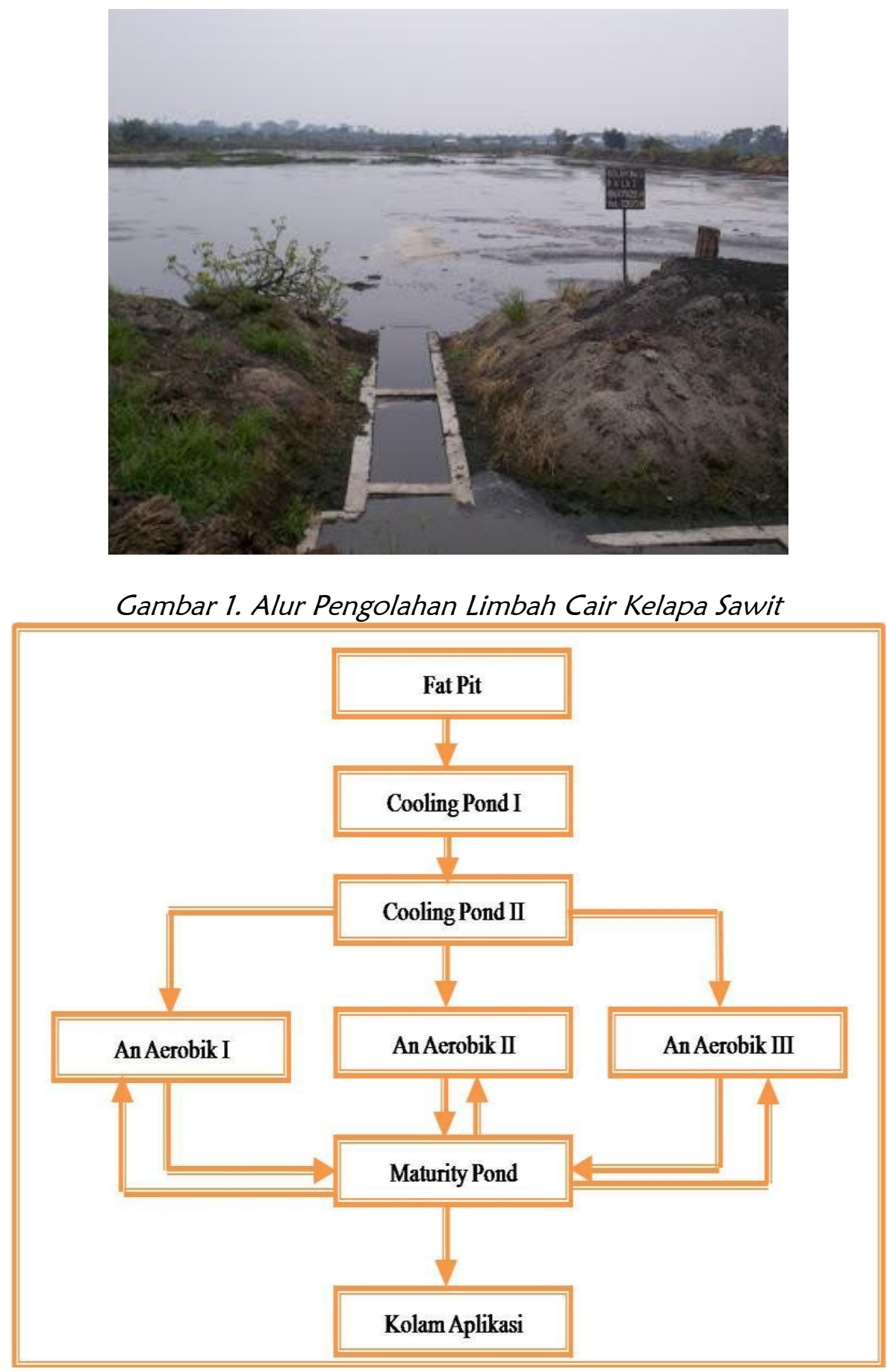

Sumber: Dokumentasi Penelitian 


\section{KESIMPULAN}

Berdasarkan analisis penelitian yang sudah dilakukan, maka dapat ditarik kesimpulan sebagai berikut:

1. Strategi pengolahan limbah cair kelapa sawit di PT AMP Plantation ini belum memenuhi standar Peraturan Menteri Perindustrian RI No 111/M-IND/PER/10/2009. Karena hanya memiliki empat jenis kolam penyaringan saja sedangkan menurut standarnya sebuah perusahaan harus memiliki lima jenis kolam penyaringan dengan cabangnya masing-masing. Kolam penyaringan yang dimiliki oleh PT AMP Plantation adalah: 1. Fat Pityang berfungsi untuk mengalirkan limbah PKS masuk kedalam fat pit. Pada fat pit ini terjadi pemanasan dengan menggunakan steam dari BPV. 2. Cooling Pond fungsinya adalah selain untuk mendinginkan limbah, cooling pond juga berfungsi untuk mengendapkan sludge. Setelah dari cooling pond I limbah kemudian masuk ke cooling pond II untuk dilakukan proses pendinginan. 3 . Kolam Anaerobic pada kolam anaerobic ini terjadi perlakuan biologis terhadap limbah dengan menggunakan bakteri metagonik yang telah ada di kolam. 4. Kolam Aplikasi setelah disaring dari kolam anaerobik 1 limbah kemudian masuk ke kolam aplikasi yang merupakan tempat pembuangan akhir limbah.

2. Limbah cair yang dihasilkan oleh pabrik kelapa sawit di PT AMP Plantation belum pernah dimanfaatkan tetapi dibiarkan saja berada di kolam aplikasi yang berada dekat dengan tempat pemukiman penduduk terutama perumahan karyawan/karyawati perusahaan.

Berdasarkan kesimpulan diatas maka penulis memberikan beberapa saran yaitu mengacu pada Peraturan Menteri

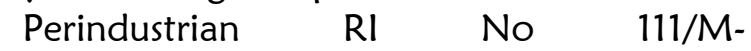
IND/PER/10/2009 bahwa strategi pengolahan limbah cair pabrik kelapa sawit Indonesia memiliki lima kolam penyaringan yang terdiri dari:

a) Fat Pit

Limbah dari PKS dialirkan masuk kedalam fat pit. Pada fat pit ini terjadi pemanasan dengan menggunakan steam dari BPV. Limbah dari fat pit ini kemudian dialirkan ke kolam cooling pond yang berguna untuk mendinginkan limbah yang telah dipanaskan.

b) Cooling Pond

Selain untuk mendinginkan limbah, cooling pond juga berfungsi untuk mengendapkan sludge setelah itu masuk ke cooling pond II untuk dilakukan proses pendinginan yang sama dengan cooling pond $\mathrm{I}$. Limbah dari cooling pond II kemudian dialirkan ke kolam anaerobic 1, 2, 3.

c) Kolam Anaerobic Pada kolam anaerobic ini terjadi perlakuan biologis terhadap limbah dengan menggunakan bakteri metagonik yang telah ada di kolam

d) Maturity Pond

Setelah dari kolam anaerobic, limbah masuk ke kolam maturity pond yang berfungsi untuk pematangan limbah (serta kenaikan $\mathrm{pH}$ dan penurunan $\mathrm{BOD}$ ).

e) Kolam Aplikasi

Setelah dari maturity pond limbah kemudian masuk ke kolam aplikasi yang merupakan tempat pembuangan akhir limbah. Limbah yang terdapat pada kolam aplikasi ini digunakan untuk pupuk tanaman kelapa sawit (land application).

\section{DAFTAR PUSTAKA}

Arikunto, Suharsimi . 2006 (Edisi Revisi VI). Prosedur Penelitian-suatu pendekatan praktik. Jakarta : Rineka Cipta 
Fauzi, Yan dkk. 2013. Kelapa Sawit.

Fatimah.2017.Jurnal.Teknologi Pengolahan Limbah Cair Kelapa Sawit.Depok :

Penebar Swadaya
Kristanto, Philip. 2016. Ekologi Industri. Yogyakarta : Andi Yogyakarta

Siregar, Sakti. 2005. Instalansi Pengolahan Air Limbah. Yogyakarta : Kanisius 